https://doi.org/10.31470/2706-7904-2020-15-204-207

\title{
ОСОБЛИВОСТІ ФУНКЦІОНУВАННЯ ЗАПОЗИЧЕНИХ ЛЕКСЕМ \\ У МОВІ УКРАЇНСЬКИХ ЗАСОБІВ МАСОВОЇ ІНФОРМАЦІЇ
}

\author{
Peculiarities of Functioning of Borrowed Lexical Items in Language \\ of Ukrainian Mass Media
}

\author{
Maryna Navalna \\ DSc. in Philology, Professor \\ Pereiaslav-Khmelnytskyi Hryhorii Skovoroda State Pedagogical University (Ukraine) \\ mnavalna@gmail.com \\ https://orcid.org/0000-0002-5064-3122
}

\begin{abstract}
The article analyzes the most commonly used foreign-language lexical items in the language of modern Ukrainian mass media. The object of the article is to study the thematic direction of foreign-language lexical items, to determine their stylistic role, as well as to indicate the instability of spelling of certain borrowings. The descriptive method and method of observation are used as main in scientific research for the study of lexical items in the language of Ukrainian periodicals of the beginning of the XXI century. At different stages of the research, the method of functional analysis was used to determine the stylistic load of lexical items. Foreign-language words are an integral part of Ukrainian vocabulary, due to some extralinguistic factors, such as Ukraine's course towards European integration, the process of globalization, restructuring of the economy, orientation towards the countries of the West, that have caused a close cultural, political, and social and economic cooperation of the Ukrainians with other nations. As the language of modern mass media shows, borrowings get into various scopes of society: economic, social and political, scientific, cultural, educational, communication, everyday life etc. Due to the active borrowing of foreign-language lexical items, we can have a threatening linguistic situation: functioning of doublets in the language, increasing the number of unwanted homonyms, borrowing of proper names without translation, borrowing of words that aim at imitating something different. Often borrowings in the Ukrainian language have different spelling, which proves the instability of spelling and which requires further scientific researches.
\end{abstract}

Key words: language of mass media; lexical borrowings; thematic groups; stylistic role; spelling features. 


\section{Вступ}

Introduction

Специфіка словникового складу української мови на сучасному етапі іiі розвитку полягає не тільки у великій кількості власне українських слів, а й передусім у значній кількості іншомовних запозичень. Запозичення - це цілком природний $\mathrm{i}$ закономірний процес, характерний для будь-якої розвиненої мови. Хоча процес запозичення $\epsilon$ нормальним явищем для всіх мов, але на початку XXI ст. спостерігається тенденція до посиленого запозичення іншомовних слів, більшу частину 3 яких становлять англіцизми. Тому функціонування слів іншомовного походження є одним 3 актуальних напрямів дослідження сучасних українських мовознавчих студій.

\section{Методи та методики дослідження Methods and Techniques of the Research}

Для вивчення іншомовної лексики в мові української періодики початку XXI ст. використано як основні метод спостереження та описовий метод. На різних етапах дослідження послуговувалися методом функціонального аналізу для визначення стилістичного навантаження лексичних одиниць.

\section{Результати \\ Results}

У виокремленні запозичень із мови українських сучасних засобів масової інформації спостерігаємо різну тематику публікацій.

Досить поширеним у мові мас-медіа є запозичення політичного спрямування лобі (англ. lobby - коридор). Цей термін позначає скоординовану практику обстоювання інтересів чи чинення тиску на законодавців і чиновників неурядовими організаціями, фінансово-промисловими групами чи етнічними спільнотами на користь того або іншого рішення.

Аналізовані лексеми функціонують у мові сучасних засобів масової інформації безвідносно до законодавчої чи політичної діяльності, напр.: «У торговельних рядах продавці лобіюють інтереси один одного» («Газета по-українськи»); «Студентське лобіювання набирає обертів» («Україна молода») та ін.

Активізувався в останні роки англіцизм снайnep (від англ. sniper - той, хто стріляє в людей з місця, де його не бачать). Здебільшого запозичення снайпер 
вживається в значенні «стрілець, що володіє мистецтвом влучної стрільби» , напр.: «Щоби не провокувати злочиния, заручники мовчки виконували усі його вимоги, наприклад, постійно мінялися місиями у машині аби ускладнити роботу снайперам» («Надзвичайні новини. Підсумки»).

Але цей англіцизм може вживатися в сюжетах про людей, які використовують зброю для вирішення власних проблем, крім того від нього також можуть утворюватися нові словосполучення, що свідчить про його переконливе освоєння системою української мови, напр.: «На Житомирщині бабка-снайперка воює з сусідами» («Надзвичайні новини», 31.08.2016); «B Одесі розшукують «снайпера», який полює за перехожими, щзо справляють свою нужду у під'їдах» («Надзвичайні новини»).

Після реформи правоохоронної системи України у 2015 році, коли на базі міліції було утворено Національну поліцію, в українській мові почало активно

вживатися запозичення коn. Kon (англ. Cop) - це поширена у США назва поліцейського. В Україні це слово також стало застосовуватися до всіх працівників нової реформованої поліції, відповідно воно часто з'являється в кримінальних новинах, напр.: «Озвірілого терориста спробував спинити полічейський, який охороняв будівлю Парламенту, але коп отримує удари ножем і гине» («Надзвичайні новини»); «Впродовж дня вони патрулювали вулиці Хмільника й зупиняли чемних водїв та пішоходів! Копи дякували їм за дотримання правил безпеки й дарували иукерки» («Свідок»); «Разом із копами місто прочісують рятувальники - шукають смертельний метал» («Надзвичайні новини»); «У покинутому автомобілі копи знайшли пістолет, а також мисливські набої 12-го калібру»(«Надзвичайні новини»). У розважальних телепрограмах українського телебачення активно функціонує лексема флешбек (від англ. flashback - ретроспективний кадр). Це слово вживається для позначення зворотного кадру, ретроспективи, сцени з минулого, оформленої як спогад та вмонтованої у потік поточної розповіді чи зображення. Напр.: «Народ, якщяо ви забули - флешбек з минулого про ту урочисту мить, про яку зараз говорить Артур» (ТСН); «Флешбек з 90-х: 10 ключових робіт українського медіа-мистецтва того часу» («День»). Подекуди аналізована лексема вживається авторами в англійській графіці, напр.: «Проект «FLASHBACK. Українське медіа-мистецтво 1990-х» продовжує лінію виставок в Мистецькому арсеналі, присвячених історії сучасного украӥнського мистецтвва - іменам, явищам, школам, періодам» («Україна молода»).

Однак це запозичення, окрім поданого вище значення, має ще одне: «раптовий, дуже чіткий спогад про минулу подію чи період, зазвичай неприємний чи болісний», напр.: «Флешбек виникає в чуттєвій пам'яті через півроку після отриманої психічної травми і характеризується «спалахом», появою певної картинки, епізоду з 
травматичної ситуації, якому зовсім не надали значення в момент травматизації» («День») та ін.

\section{Висновки \\ Conclusions}

Слова іншомовного походження - невід’ємна частина української лексики. Їх запозичення тісно пов'язане 3 історією нашого народу, що на різних етапах формування та розвитку власної державності вступав у багатоманітні політичні, соціально-економічні та культурні відносини з іншими народами світу і, таким чином, збагачував та змінював свою мову. Процес запозичення з англійської мови зараз став інтенсивним як ніколи. Цьому, безумовно, сприяють позамовні чинники: курс на інтеграцію України в ЄС, процес глобалізації, перебудова економіки, орієнтація на країни Заходу спричинили тісну культурну, політичну та соціально-економічну взаємодію українського народу з народами світу.

Як засвідчує мова сучасних засобів масової інформації, запозичення проникають до різних сфер діяльності суспільства: економічної, суспільнополітичної, наукової, культурної, освітньої, до засобів зв'язку, до побуту тощо. Унаслідок активному запозиченню іншомовних лексем можемо мати загрозливу мовну ситуацію: функціонування в мові дублетів, збільшення кількості небажаних омонімів, запозичення власних назв без перекладу, запозичення слів, що мають на меті імітувати чуже.

\section{Література \\ References}

Молоткіна, Ю. (2017). Різні способи написання новітніх англіцизмів в українській мові. Науковий вісник Дрогобицького Державного Педагогічного Університету імені Івана Франка. Серія «Філологічні науки». Мовознавство, 7, 119-123.

Полякова, Т.М. (2002). Лексичне запозичення niap у російському публіцистичному стилі (на матеріалі російськомовних ЗМІ останнього десятиліття XX - початку XXI ст.). Мовознавство, 4-5, 66-72.

Сімонок, В.П. (2000). Семантико-функиіональний аналіз іншомовної лексики в сучасній українській мовній картині світу. Харків: Основа. 